\title{
On-Line Hemodiafiltration: All That Glitters Is Not Gold
}

\author{
Marco Marano ${ }^{\mathrm{a}}$ Marco Capasso $^{\mathrm{b}}$ Tommaso Cicchella ${ }^{\mathrm{a}}$ \\ a Unit of Hemodialysis, 'Maria Rosaria Clinic', Pompeii, and ${ }^{b}$ Centro Emodialisi San Giorgio, \\ San Giorgio a Cremano, Italy
}

\section{Dear Editor,}

We read with great interest the September 2015 supplement of Blood $\mathrm{Pu}$ rification entitled 'Is Hemodiafiltration the Current Gold Standard?' and we would briefly comment on a few topics that have not been discussed there.

Having still unresolved the question of whether online hemodiafiltration (HDF) improves patient survival or not [1], the heart of the matter is what convection volume is required to achieve reduction in mortality [2] or whether inconsistent results of clinical trials may possibly be due to bias [3]. Other hypotheses to explain the failure in improving mortality rate are basically lacking in required facts and information. We believe that 2 neglected issues should be considered.

We have already underlined [4] that the burden of glucose delivered by online HDF could negatively affect morbidity and mortality rates of hemodialysis patients also having diabetes. This is in agreement with our thought that the highest hazard ratio for all-cause mortality is associated with the diabetes status reported in the ESHOL study [5].

Similarly, we would conjecture that the load of carbonic dioxide $\left(\mathrm{CO}_{2}\right)$ by online HDF could deteriorate survival rates of patients with chronic obstructive pulmonary disease (COPD) and possibly of those with marginal cardiopulmonary status unable to handle any $\mathrm{CO}_{2}$ overload.
In online $\mathrm{HDF}$, the source of $\mathrm{CO}_{2}$ is just the infusate. As known, it is simply ultrapure dialysate infused as replacement fluid. It should be stressed that the dialysate contains a remarkable amount of $\mathrm{CO}_{2}$ (close to $100 \mathrm{~mm} \mathrm{Hg} \mathrm{[6],} \mathrm{as} \mathrm{a} \mathrm{result} \mathrm{of} \mathrm{the}$ reaction of the acid by the buffer in the final diluted dialysate). Note that in the post-dilution mode, the $\mathrm{CO}_{2}$ is delivered directly into a patient's bloodstream. It is needless to say that the larger volume of infusate, the heavier the burden of $\mathrm{CO}_{2}$ (and of glucose). It is to be noted that this load is in addition to the amount of $\mathrm{CO}_{2}$

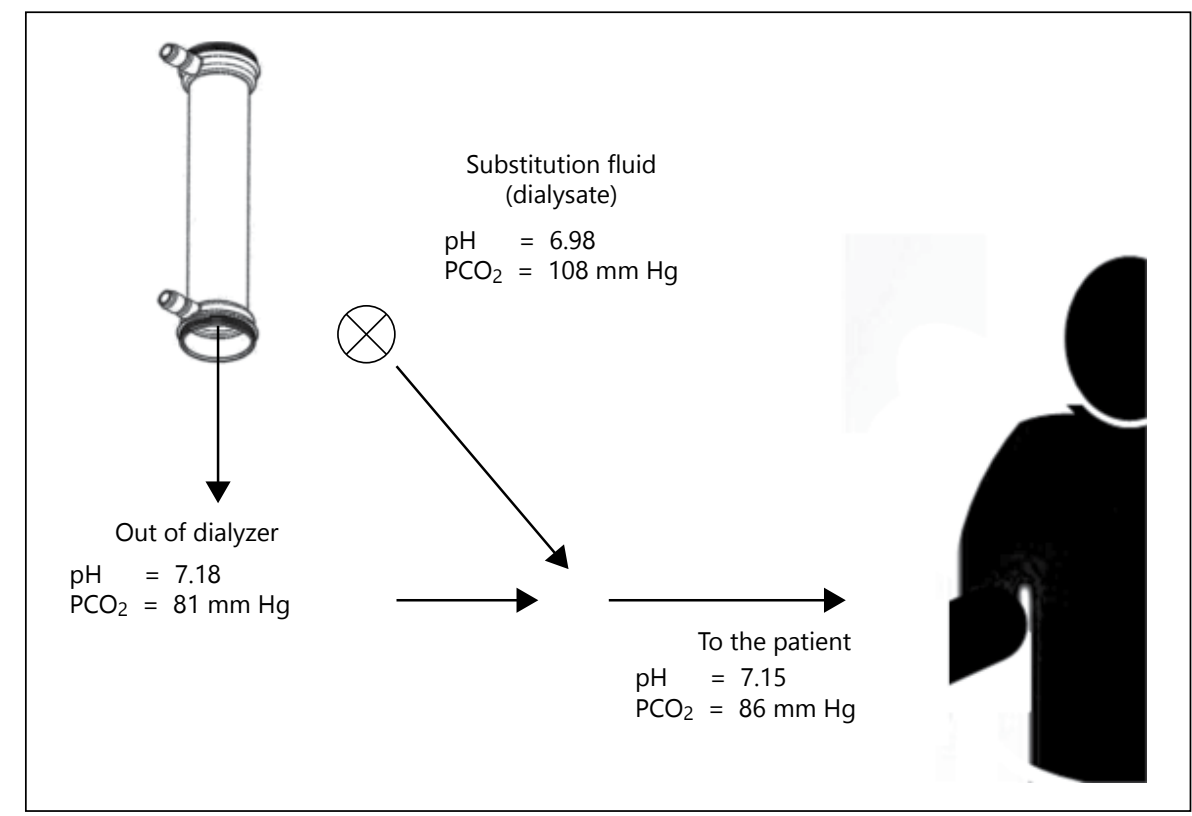

Fig. 1. Example of gas analysis in on-line hemodiafiltration. $\mathrm{PCO}_{2}$ is for partial pressure of carbon dioxide.

\section{KARGER}

E-Mail karger@karger.com

www.karger.com/bpu
(C) 2016 S. Karger AG, Base

$0253-5068 / 16 / 0414-0315 \$ 39.50 / 0$
Marco Marano, MD

Hemodialysis Unit

Maria Rosaria Clinic, via Colle San Bartolomeo 50

IT-80045 Pompeii (Italy)

E-Mail marano965@gmail.com 
diffusing through the dialyzer, just as it occurs during bicarbonate dialysis [7] (fig. 1). In conclusion, the delivery of both glucose and $\mathrm{CO}_{2}$ might affect morbidity and mortality of patients in online HDF (mainly in post-dilution mode). Recalling also the increasing prevalence of diabetes and COPD among ESKD patients [8, 9]

\section{References}

1 Locatelli F, Violo L, Longhi S, Del Vecchio L: Current evidence in haemodiafiltration. Blood Purif 2015;40(suppl 1):24-29.

2 Canaud B, Barbieri C, Marcelli D, et al: Optimal convection volume for improving patient outcomes in an international incident dialysis cohort treated with online hemodiafiltration. Kidney Int 2015;88:1108-1116.

3 Peters SA, Bots ML, Canaud B, et al: Haemodiafiltration and mortality in end-stage kidney disease patients: a pooled individual participant data analysis from four randomized controlled trials. Nephrol Dial Transplant 2015;pii:gfv349. we look forward to randomized control trials focused on these issues. In the meanwhile, we feel that it is not advisable to recommend the use of 'the highest possible convection dose' and of 'the highest possible infusion flow rate for the individual characteristics' [10]. On the contrary, we would suggest that one exercises cau- tion when using online HDF in diabetics, COPD and cardiovascular high-risk patients.

\section{Disclosure Statement}

None declared.
4 Marano M, Cirillo G: The forgotten issue of glucose delivery to diabetes patients in on-line hemodiafiltration. Ther Apher Dial 2015, DOI: $10.1111 / 1744-9987.12385$.

5 Maduell F, Moreso F, Pons M, et al: High-efficiency postdilution online hemodiafiltration reduces all-cause mortality in hemodialysis patients. J Am Soc Nephrol 2013;24: 487-497.

6 Golper TA, Fissell R, Fissell WH, et al: Hemodialysis: core curriculum 2014. Am J Kidney Dis 2014;63:153-163.
7 Marano M, D'Amato A, Patriarca A, et al: Carbon dioxide and acetate-free biofiltration: a relationship to be investigated. Artif Organs 2015;3911:960-964.

8 Collins AJ, Foley RN, Chavers B: US renal data system 2013 annual data report. Am J Kidney Dis 2014;63(1 suppl):A7.

9 Kent BD, Eltayeb EE, Woodman A, et al: The impact of chronic obstructive pulmonary disease and smoking on mortality and kidney transplantation in end-stage kidney disease. Am J Nephrol 2012;36:287-295.

10 Maduell F: Is there an 'optimal dose' of hemodiafiltration? Blood Purif 2015;40(suppl 1): $17-23$. 